Bangladesh J. Bot. 48(1): 65-74, 2019 (March)

\title{
OPTIMIZATION OF CULTURAL PARAMETERS FOR PECTIN METHYLESTRASE AND POLYGALACTURONASE PRODUCTION FROM SCHIZOPHYLLUM COMMUNE IN SOLID STATE FERMENTATION
}

\author{
Tahir Mehmood*1, Tasmia Saman, Muhammad Asgher ${ }^{2}$, Muhammad Irfan ${ }^{3}$, \\ Zahid AnWar ${ }^{4}$, Fareeha Nadeem ${ }^{4}$ and Ayesha Siddiqa ${ }^{4}$ \\ Department of Chemistry, University of Sargodha, 40100, Sargodha, Pakistan
}

Keywords: Optimization, Methylestrase, Polygalacturonase, Solid state fermentation

\begin{abstract}
The aim of this study was optimization of pectinolytic enzymes i.e. pectin methylesterase and polygalacturonase from Schizophyllum commune using the mosambi peels as substrate in a solid state fermentation process. Results revealed that maximum pectin methylesterase activity of $394.82 \mathrm{U} / \mathrm{ml}$ was observed at $\mathrm{pH}$ 6, temperature $35^{\circ} \mathrm{C}$, time period of 3 days, substrate concentration of $3 \mathrm{~g}$ and $3 \mathrm{ml}$ inoculum size. While polygalacturonase showed maximum activity of $381.69 \mathrm{U} / \mathrm{ml}$ at $\mathrm{pH} 4$, temperature $45^{\circ} \mathrm{C}$, time period of 1 day, substrate concentration $25 \mathrm{~g}$ and $5 \mathrm{ml}$ inoculum size. Statistical analysis revealed that the proposed model was found very significant as indicated by $p$-values.

\section{Introduction}

The reactions involved in the preparation of different food products are catalyzed by many enzymes. During these reactions, many intermediate processes are shortened due to use of enzymes so it is one of the significant tools in modern food processes. A huge amount of industrial enzymes are classified into different groups. Out of these groups, pectinases are the most significant enzymes used in vegetable and fruit industries (Tapre and Jain 2014). The pectinases or pectinolytic enzymes are the group of enzymes which are involved in pectin degradation (Murudula and Anitharaj 2011). Pectic substances or pectin are the complex polysaccharides present in the middle lamella of plant cell wall (Sandhya and Kurup 2013). In its structure pectin is homopolymeric, made up of a partially methylated poly-a- $(1,4)$-galacturonic acid (Torres et al. 2006).

Pectin methylesterase (PME, EC 3.1.1.11) is an abundant enzyme in plants. This enzyme deesterifies the methoxylated pectin in the plant cell wall (Demirdoven and Baysal 2014). During its reaction, PME has the capacity to release methoxyl group from pectin chain to form carboxylate groups (polygalacturonic acid). In addition to this, methanol and $\mathrm{H}_{3} \mathrm{O}^{+}$are released (Kushani et al. 2014). Pectin methylesterase plays important role in plants as well as in food industry (Poturcu et al 2017). The effect of PME in food industry has been widely considered. It produces required effects in quality enhancement as well as unwanted effects in some drinks (Jesus et al. 2017).

Polygalacturonases or hydrolytic depolymerases are enzymes which are involved in the degradation of pectin or pectic substances. They have widespread applications in textile and food processing, management of pectic waste waters and degumming of plant fibres (Torres et al. 2006). Polygalacturonase (PG) degrades pectin into D-galacturonic acid monomers and is used broadly in food industry particularly for juice clarification (Yadav et al. 2015).

\footnotetext{
*Author for correspondence: <tahiruosbiochem@yahoo.com>. ${ }^{1}$ Institute of Biochemistry and Biotechnology, University of Veterinary and Animal Sciences, 54000, Lahore, Pakistan. ${ }^{2}$ Department of Biochemistry, University of Agriculture, Faisalabad, Pakistan. ${ }^{3}$ Department of Biotechnology, University of Sargodha, 40100 Sargodha, Pakistan. ${ }^{4}$ Department of Biochemistry and Biotechnology, University of Gujrat, Gujrat,
} Pakistan.
\end{abstract}


Existence of pectinolytic enzymes has been described in many fungi and bacteria species but majority of industrial preparations of pectic enzymes are derived from fungal source (Kushani et al. 2014). Schizophyllum commune is a wood-rotting basidiomycetes. S. commune is spread all over the world and is easily identifiable due to its fan-shaped basidiocarp and a split gill on the base. Its fruiting bodies are collected from the wild and have been utilized as food, particularly in the southern part of Thailand. Various fibrinolytic enzymes are produced from $S$. commune. Furthermore, its metabolites, enzymes and polysaccharides have been used for several products (Patcharaporn et al. 2008).

In the process of fermentation, microorganisms like bacteria and fungi are used to produce enzymes. There are two techniques of fermentation for the production of enzymes i.e. submerged fermentation and solid-state fermentation. Submerged fermentation comprises the manufacturing of enzymes by microbes in a liquid nutrient media (Renge and Khedkar 2012). Solid-state fermentation (SSF) is a process that takes place on insoluble material that as support as well as a source of nutrients. This process uses low amount of water, under the action of fermenting material (Alcantara et al. 2010). As compared to other microorganisms, fungi usually grow on solid substrate. That's why solid state fermentation suggests highest opportunities when fungi are used (Bhargav et al. 2008).

Optimization means to improve the activity of a procedure, a system, or a product with the aim of obtaining the extreme advantage from it. Optimization has been usually used in analytical chemistry as a source of determining situations at which a process gives the best probable output (Marcos et al. 2008). Response Surface Methodology (RSM) is a collection of mathematical and statistical tools suitable for improving, developing, and optimizing methods (Carley et al. 2004). Response surface methodology (RSM) is a most popular method which is utilized in optimization of cultural conditions and other important parameters that are useful in synthesis of various biomolecule (Mehmood at el. 2018, Naz et al. 2017). The present study aims at optimizing production of pectin methylesterase (PME) and polygalacturonase (PG) through solid state fermentation from Schizophyllum commune by utilizing agro-industrial waste (peels of mosambi).

\section{Materials and Methods}

Five variables i.e. $\mathrm{pH}$, temperature, time period, substrate concentration and inoculum size were optimized through central composite design (CCD) of response surface methodology.

Agro-industrial waste mosambi peels were used as substrate for pectinolytic enzyme i.e PME and PG production. The substrate was collected from the local fruit market of Gujrat, Pakistan. Peels were washed with distilled water to remove impurities and dried at $50{ }^{\circ} \mathrm{C}$ for $2-3$ days. The dried peels were milled into fine powder for further use.

Schizophyllum commune a fungal strain was used for the production of pectinolytic enzymes. The fungal strain was grown on potato dextrose agar (PDA) slants and stored at $30^{\circ} \mathrm{C}$. Inoculum media were prepared in 250 Erlenmeyer flask. The inoculum media comprised of (\%): glucose 2; $\mathrm{MgSO}_{4} .7 \mathrm{H}_{2} \mathrm{O} 0.05 ; \mathrm{KH}_{2} \mathrm{PO}_{4} .7 \mathrm{H}_{2} \mathrm{O} 0.02 ;\left(\mathrm{NH}_{4}\right)_{2} \mathrm{SO}_{4} 0.05 ; \mathrm{CaCl}_{2} 0.05$ and autoclaved at $120^{\circ} \mathrm{C}$ for 30 minutes. Then a loop full of sporulation culture of Shizophyllum commune was transferred aseptically to inoculum media. The flask was kept in water bath shaker at $35^{\circ} \mathrm{C}$ with shaking speed of $120 \mathrm{rpm}$ for 3 - 4 days.

The specific amount of substrate was moistened with medium of different $\mathrm{pH}$ and sterilized at $121^{\circ} \mathrm{C}$ for $15 \mathrm{~min}$. After that it was inoculated with different volumes of inoculum size and incubated at different temperatures for various time periods as per statistical design. After termination of the fermentation period, enzyme was extracted and enzyme activity was measured. 
Solid state fermentation (SSF) parameters were optimized through response surface methodology for PME and PG production. Twenty-six trials for 5 parameters namely pH (4 - 10), temperature $\left(15-58^{0} \mathrm{C}\right)$, time period $(1-7$ days $)$, substrate concentration $(3-35 \mathrm{~g})$ and inoculum size $(1-7 \mathrm{ml})$ were applied.

Enzyme was extracted after 3 days by adding $50 \mathrm{ml}$ distilled water in each flask followed by shaking at $120 \mathrm{rpm}$ for $30 \mathrm{~min}$. The experimental mass was filtered through Whatman filter paper No.1 and filtrate obtained was collected in $50 \mathrm{ml}$ falcon tubes. The filtrate was then centrifuged for $10 \mathrm{~min}$ at $4000 \mathrm{rpm}$ and $4^{0} \mathrm{C}$. Clear supernatant containing crude enzyme was saved and further analyzed for pectin lyase activity by spectrophotometrically (Ali et al. 2016).

For PME activity $2 \mathrm{ml}$ pectin $(0.5 \mathrm{~g} / \mathrm{ml}$ of pectin), $100 \mu \mathrm{l}$ bromocresol green $(0.01 \mathrm{~g}$ bromocresol green in $100 \mathrm{ml}$ acetate buffer) and $0.5 \mathrm{ml}$ of crude enzyme was taken in test tubes. The reaction mixture was incubated at $60^{\circ} \mathrm{C}$ for $2 \mathrm{~min}$. Then absorbance was taken spectrophotometrically at $620 \mathrm{~nm}$. For PG activity, $1 \mathrm{ml}$ crude enzyme and $1 \mathrm{ml}$ polygalacturonic acid substrate was taken and the reaction mixture was incubated at $35^{\circ} \mathrm{C}$ for $20 \mathrm{~min}$. After that 3 $\mathrm{ml}$ of DNS was added and boiled for 15 minutes. By adding distilled water volume was made up to $10 \mathrm{ml}$. cooled it at room temperature and absorbance was taken spectrophotometrically at 550 nm (Hubert et al. 2017).

All the data were statistically analyzed and analysis of variance was performed using Statistica software $99^{\text {th }}$ version.

\section{Results and Discussion}

In the present study central composite design of response surface methodology was applied to investigate the effect of 5 parameters on pectin methylesterase and polygalacturonase production. Response surface methodology has been effectively used to optimize biotechnological and biochemical procedures linked to food systems (Murudulla and Anitharaj 2011). Experiments were conducted and the response was calculated through second order polynomial regression equation (Eq. 1, 2). The parameters used were $\mathrm{pH}(\mathrm{A})$, temperature (B), substrate concentration (C), time period (D) and inoculum size (E). Table 1 shows that PME activity ranged from 114.0 $\mathrm{U} / \mathrm{ml}$ to $394.82 \mathrm{U} / \mathrm{ml}$. The maximum activity of PME $394.82 \mathrm{U} / \mathrm{ml}$ was observed at $\mathrm{pH} 6$, temperature $35^{\circ} \mathrm{C}$, time period of 3 days, substrate concentration of $3 \mathrm{~g}$ and $3 \mathrm{ml}$ inoculum size, while polygalacturonase showed maximum activity of $381.69 \mathrm{U} / \mathrm{ml}$ at $\mathrm{pH} 4$, temperature $45^{\circ} \mathrm{C}$, time period of 5 days, substrate concentration $25 \mathrm{~g}$ and $1 \mathrm{ml}$ inoculum size (Table 1). Shweta et al. (2006) studied the use of response surface methodology (RSM) to optimize ecological factors for pectinase production from Rhizopus species. Palaniyappan et al. (2009) also studied optimization method using RSM to monitor the effect of different parameters on pectinase production.

Pectin methylestrase activity $(\mathrm{U} / \mathrm{ml})=-1110.25-0.60 \mathrm{~A}+69.88 \mathrm{~B}+45.54 \mathrm{C}+16.69 \mathrm{D}+$ 193.05 $\mathrm{E}+6.89 \mathrm{~A}^{2}-0.76 \mathrm{~B}^{2}+8.04 \mathrm{C}^{2}+0.32 \mathrm{D}^{2}-5.74 \mathrm{E}^{2}-1.27 \mathrm{AB}+0.61 \mathrm{AC}-2.27 \mathrm{BC}-2.77$ $\mathrm{AD}-0.17 \mathrm{BD}-1.30 \mathrm{CD}-9.26 \mathrm{AE}-1.76 \mathrm{BE}-8.72 \mathrm{CE}-2.28 \mathrm{DE}$ Eq. 1.

Polygalacturonase activity $(\mathrm{U} / \mathrm{ml})=16.5738+25.7745 \mathrm{~A}-11.8943 \mathrm{~B}+45.3915 \mathrm{C}+11.8493$ $\mathrm{D}+89.3141 \mathrm{E}+2.4818 \mathrm{~A}^{2}+0.1747 \mathrm{~B}^{2}+45.3915 \mathrm{C}^{2}+11.8493 \mathrm{D}^{2}-5.7094 \mathrm{E}^{2}-0.2558 \mathrm{AB}-6.9252$ $\mathrm{AC}+0.5716 \mathrm{BC}-1.5472 \mathrm{AD}+0.1650 \mathrm{BD}-0.0244 \mathrm{CD}-3.7113 \mathrm{AE}+0.5054 \mathrm{BE}-12.7427 \mathrm{CE}$ - 0.8278 DE Eq. 2.

Statistical analysis shows that the proposed model was highly significant as revealed by Fvalue and p-value of 41.4483, 20.6878 and 0.000304, 0.001637for PME and PG, respectively (Table 2). The goodness of fit of the model was determined by coefficient of determination $\left(\mathrm{R}^{2}\right)$ having value of 0.994 and 0.988 for PME and PG indicating the accuracy of the model (Fig. 1). The authenticity of the model was further supported by adjusted $\mathrm{R}^{2}$ having value of 0.97 and 
0.9403 which indicated that only 3 and $6 \%$ of variation was not predicted by the model for PME and PG, respectively.

Table 1. Central composite design for PME and PG by Schizophyllum commune.

\begin{tabular}{|c|c|c|c|c|c|c|c|}
\hline Run No. & A & B & $\mathrm{C}$ & $\mathrm{D}$ & E & PME (U/ml) & $\mathrm{PG}(\mathrm{U} / \mathrm{ml})$ \\
\hline 1 & 8 & 20 & 5 & 5 & 5 & 376.9200 & 96.8500 \\
\hline 2 & 6 & 35 & 3 & 15 & 3 & 292.5500 & 204.2800 \\
\hline 3 & 4 & 20 & 5 & 25 & 5 & 254.2000 & 104.4300 \\
\hline 4 & 6 & 35 & 1 & 15 & 3 & 374.0800 & 220.6400 \\
\hline 5 & 6 & 45 & 3 & 15 & 3 & 152.2200 & 297.4000 \\
\hline 6 & 4 & 45 & 5 & 25 & 1 & 263.1500 & 381.6900 \\
\hline 7 & 6 & 35 & 3 & 15 & 7 & 114.3800 & 123.4900 \\
\hline 8 & 6 & 20 & 3 & 15 & 3 & 201.4700 & 175.3400 \\
\hline 9 & 6 & 35 & 3 & 35 & 3 & 285.8800 & 125.9100 \\
\hline 10 & 8 & 20 & 5 & 25 & 1 & 234.7300 & 136.2700 \\
\hline 11 & 8 & 20 & 1 & 5 & 1 & 246.0300 & 235.1910 \\
\hline 12 & 4 & 45 & 5 & 5 & 5 & 243.6300 & 246.6910 \\
\hline 13 & 4 & 20 & 1 & 5 & 5 & 375.6600 & 238.8830 \\
\hline 14 & 6 & 35 & 7 & 15 & 3 & 303.9800 & 226.1300 \\
\hline 15 & 6 & 35 & 3 & 3 & 3 & 394.8200 & 194.5800 \\
\hline 16 & 8 & 45 & 5 & 5 & 1 & 311.4200 & 260.8500 \\
\hline 17 & 4 & 20 & 1 & 25 & 1 & 271.3700 & 140.7600 \\
\hline 18 & 4 & 35 & 3 & 15 & 3 & 379.9800 & 268.5500 \\
\hline 19 & 8 & 45 & 1 & 25 & 1 & 242.3700 & 211.2640 \\
\hline 20 & 8 & 45 & 1 & 5 & 5 & 331.3100 & 342.5900 \\
\hline 21 & 8 & 20 & 1 & 25 & 5 & 124.1800 & 158.4080 \\
\hline 22 & 4 & 20 & 5 & 5 & 1 & 250.3300 & 203.8900 \\
\hline 23 & 4 & 45 & 1 & 5 & 1 & 376.8800 & 107.4800 \\
\hline 24 & 4 & 45 & 1 & 25 & 5 & 362.8800 & 347.7300 \\
\hline 25 & 10 & 35 & 3 & 15 & 3 & 275.9900 & 218.5900 \\
\hline 26 & 6 & 35 & 3 & 15 & 0.5 & 310.1900 & 191.3790 \\
\hline
\end{tabular}

$\mathrm{A}=\mathrm{pH}, \mathrm{B}=$ temperature $\left({ }^{\mathrm{o}} \mathrm{C}\right), \mathbf{C}$. time period (days), D. Substrate concentration $(\mathrm{g})$ and E. Inoculum size (ml). 

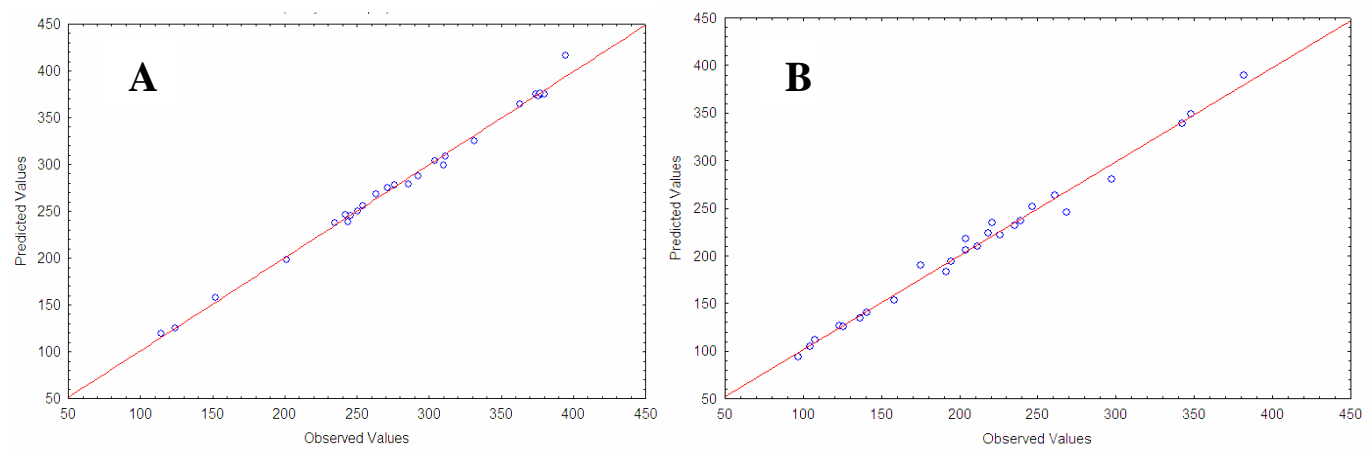

Fig. 1. Graph between observed and predicted values of PME (A) and PG (B).
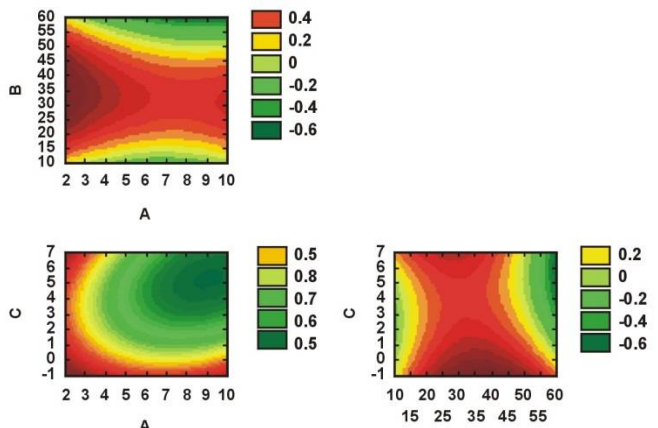

$$
\text { B }
$$
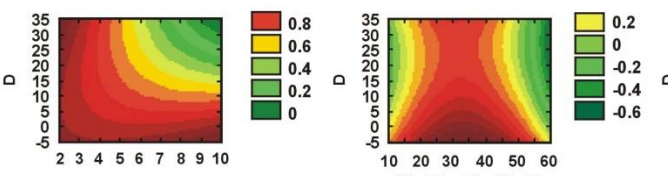

A

B
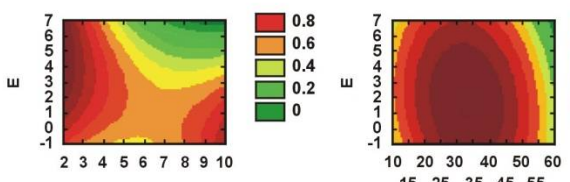

$\begin{array}{lllll}20 & 30 \quad 40 \quad 50 & 60\end{array}$

B
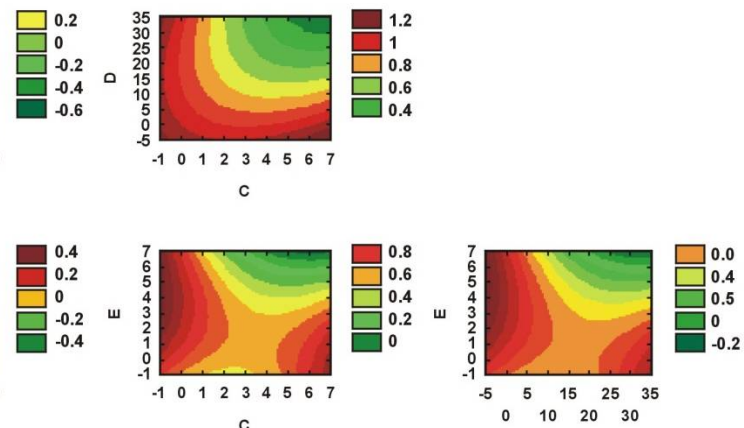

D

Fig. 2. Contour plots for PME indicating the interaction of different variables.

Figs 2 and 3 illustrated the contour plots for PME production by Schizophyllum commune in solid state fermentation. These plots were made from two selected independent variables and the value of third variable was kept persistent because it is the central value to get optimum conditions for maximum PME production. The different colors in these plots indicated different levels of PME production between two independent parameters and keeping third parameter at constant value. These graphs showed that each parameter had significant effect on PME production by Schizophyllum commune in solid state fermentation. 
Table 2. Analysis of variance for PME (U/ml) and PG (U/ml) production by $S$. commune.

\begin{tabular}{|c|c|c|c|c|c|c|}
\hline Enzyme & Effect & $\begin{array}{l}\text { Degree of } \\
\text { freedom }\end{array}$ & $\begin{array}{l}\text { Sum of } \\
\text { squares }\end{array}$ & $\begin{array}{l}\text { Mean } \\
\text { square }\end{array}$ & F-value & p-value \\
\hline \multirow[t]{22}{*}{ PME } & Model & 20 & 153080.3 & 7654.016 & 41.44483 & 0.000304 \\
\hline & A & 1 & 0.3200 & 0.32 & 0.0017 & 0.968629 \\
\hline & $\mathrm{A}^{2}$ & 1 & 10079.40 & 10079.40 & 54.5778 & 0.000715 \\
\hline & B & 1 & 43248.36 & 43248.36 & 234.1804 & 0.000022 \\
\hline & $\mathrm{B}^{2}$ & 1 & 38583.37 & 38583.37 & 208.9206 & 0.000029 \\
\hline & $\mathrm{C}$ & 1 & 1993.53 & 1993.53 & 10.7946 & 0.021821 \\
\hline & $\mathrm{C}^{2}$ & 1 & 13707.29 & 13707.29 & 74.2220 & 0.000348 \\
\hline & $\mathrm{D}$ & 1 & 6549.44 & 6549.44 & 35.4638 & 0.001909 \\
\hline & $\mathrm{D}^{2}$ & 1 & 14946.38 & 14946.38 & 80.9314 & 0.000283 \\
\hline & $\mathrm{E}$ & 1 & 34879.77 & 34879.77 & 188.8664 & 0.000037 \\
\hline & $E^{2}$ & 1 & 7757.52 & 7757.52 & 42.0053 & 0.001304 \\
\hline & $\mathrm{AB}$ & 1 & 9916.93 & 9916.93 & 53.6980 & 0.000742 \\
\hline & $\mathrm{AC}$ & 1 & 55.450 & 55.46 & 0.3003 & 0.607287 \\
\hline & $\mathrm{BC}$ & 1 & 31642.28 & 31642.28 & 171.3361 & 0.000046 \\
\hline & $\mathrm{AD}$ & 1 & 28873.27 & 28873.27 & 156.3424 & 0.000058 \\
\hline & $\mathrm{BD}$ & 1 & 4409.07 & 4409.07 & 23.8742 & 0.004529 \\
\hline & $\mathrm{CD}$ & 1 & 6405.14 & 6405.14 & 34.6824 & 0.002006 \\
\hline & $\mathrm{AE}$ & 1 & 12937.14 & 12937.14 & 70.0518 & 0.00039 \\
\hline & $\mathrm{BE}$ & 1 & 19217.41 & 19217.41 & 104.0581 & 0.000155 \\
\hline & $\mathrm{CE}$ & 1 & 11473.91 & 11473.91 & 62.1287 & 0.000528 \\
\hline & $\mathrm{DE}$ & 1 & 19579.72 & 19579.72 & 106.0199 & 0.000149 \\
\hline & Error & 5 & 923.40 & 184.68 & & \\
\hline \multirow[t]{22}{*}{ PG } & Model & 20 & 3.10 & 3.10 & 0.00886 & 0.928658 \\
\hline & A & 1 & 573.55 & 573.55 & 1.63716 & 0.256871 \\
\hline & $A^{2}$ & 1 & 1306.87 & 1306.87 & 3.73035 & 0.111289 \\
\hline & B & 1 & 1253.08 & 1253.08 & 3.57683 & 0.117172 \\
\hline & $\mathrm{B}^{2}$ & 1 & 2054.45 & 2054.45 & 5.86426 & 0.059997 \\
\hline & $\mathrm{C}$ & 1 & 1980.22 & 1980.22 & 5.65239 & 0.063363 \\
\hline & $\mathrm{C}^{2}$ & 1 & 521.26 & 521.26 & 1.28791 & 0.276933 \\
\hline & $\mathrm{D}$ & 1 & 3302.18 & 3302.18 & 9.42582 & 0.027779 \\
\hline & $\mathrm{D}^{2}$ & 1 & 6222.30 & 6222.30 & 17.76108 & 0.008373 \\
\hline & $\mathrm{E}$ & 1 & 7465.50 & 7465.50 & 21.30970 & 0.005755 \\
\hline & $E^{2}$ & 1 & 7663.63 & 7663.63 & 21.87525 & 0.005448 \\
\hline & $\mathrm{AB}$ & 1 & 400.21 & 400.21 & 1.14236 & 0.334016 \\
\hline & $\mathrm{AC}$ & 1 & 7235.80 & 7235.80 & 20.65403 & 0.006142 \\
\hline & $\mathrm{BC}$ & 1 & 1998.32 & 1998.32 & 5.70405 & 0.062518 \\
\hline & $\mathrm{AD}$ & 1 & 9028.67 & 9028.67 & 25.77165 & 0.003846 \\
\hline & $\mathrm{BD}$ & 1 & 4200.57 & 4200.57 & 11.99020 & 0.017990 \\
\hline & $\mathrm{CD}$ & 1 & 2.24 & 2.24 & 0.00639 & 0.939403 \\
\hline & $\mathrm{AE}$ & 1 & 2078.15 & 2078.15 & 5.93193 & 0.0058976 \\
\hline & $\mathrm{BE}$ & 1 & 1579.78 & 1579.78 & 4.50936 & 0.087116 \\
\hline & $\mathrm{CE}$ & 1 & 24498.27 & 24498.27 & 69.92845 & 0.000400 \\
\hline & $\mathrm{DE}$ & 1 & 2584.83 & 2584.83 & 7.37821 & 0.041960 \\
\hline & Error & 5 & 1751.67 & 350.33 & & \\
\hline
\end{tabular}




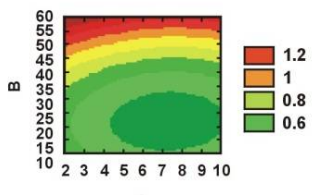

A
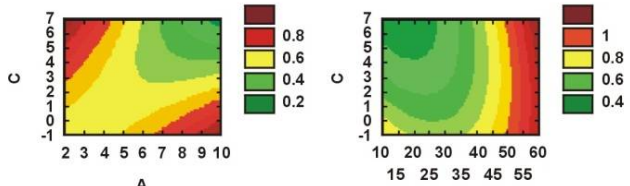

B
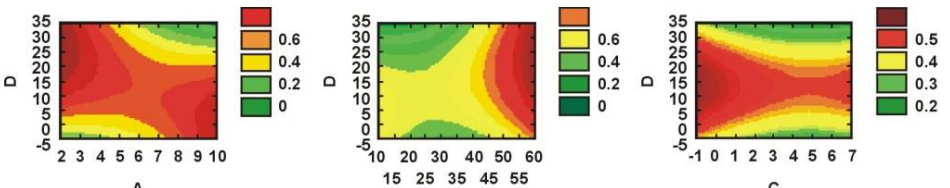

B
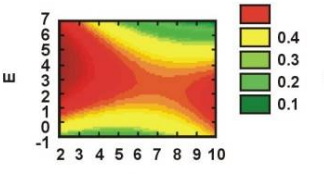

A
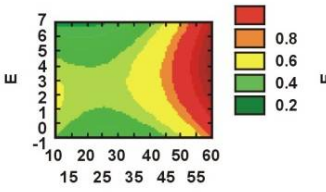

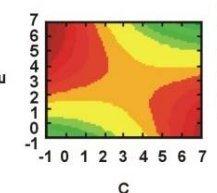

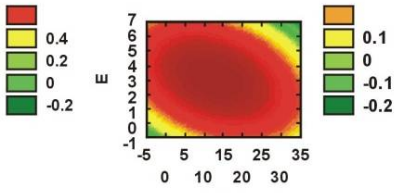

Fig. 3. Contour plots for PG indicating the interaction of different variables.

Fig. 4 explained the desirability chart for PME production by $S$. commune in solid state fermentation. This chart depicted that if value of parameter A is 6, parameter B is 32.8 , parameter $\mathrm{C}$ is 3, parameter $\mathrm{D}$ is 14.92 and parameter $\mathrm{E}$ is 2.98 then the maximum predicted response will be $439.69 \mathrm{U} / \mathrm{ml}$ and minimum response will be $125.74 \mathrm{U} / \mathrm{ml}$. Using these values of different paramters, the response was very close to the predicted values which validated the model prediction.

Enzyme manufacturing from microbes has grown a lot of attention at the industrial scale (Renge et al. 2012). The biotechnological potential of pectinolytic enzymes from microorganisms has drawn much of attention from various researchers worldwide as likely biological catalysts in a variety of industrial processes (Hossam and Hamdy 2011). Agro-industrial wastes are potential source for pectinolytic enzyme manufacturing for utilization in industry because of their higher stability under extreme environments and extensive substrate specificity (Siumara et al. 2010).

In this study Schizophyllum commune was preferred as microorganism for the production of pectinolytic enzymes through solid state fermentation utilizing Sweet limetta (mosambi peels) as an agro-industrial waste. The production of pectinolytic enzymes i.e. pectin methylesterase and polygalacturonase was optimized through response surface methodology. Response surface methodology has been effectively used to optimize biotechnological and biochemical procedures linked to food systems (Murudula and Anitharaj 2011). As described above in the results that PME showed maximum activity of $394.82 \mathrm{U} / \mathrm{ml}$ at $\mathrm{pH} 6$, temperature $35^{\circ} \mathrm{C}$, substrate concentration $3 \mathrm{~g}, 3 \mathrm{ml}$ inoculum size and 3 days of fermentation period while PG showed maximum activity of $381.69 \mathrm{U} / \mathrm{ml}$ at $\mathrm{pH} 4$, temperature $45^{\circ} \mathrm{C}$, time period of 5 day, substrate concentration $25 \mathrm{~g}$ and $1 \mathrm{ml}$ inoculum size. The utilization of mosambi peels as substrate in SSF provide a cheaper way of enzyme production. The composition of medium is very important for 
enzyme production. Enzyme production is greatly affected by change in $\mathrm{pH}$ and temperature of the fermented medium. If $\mathrm{pH}$ or temperature rises above or below the optimum, it will greatly affect

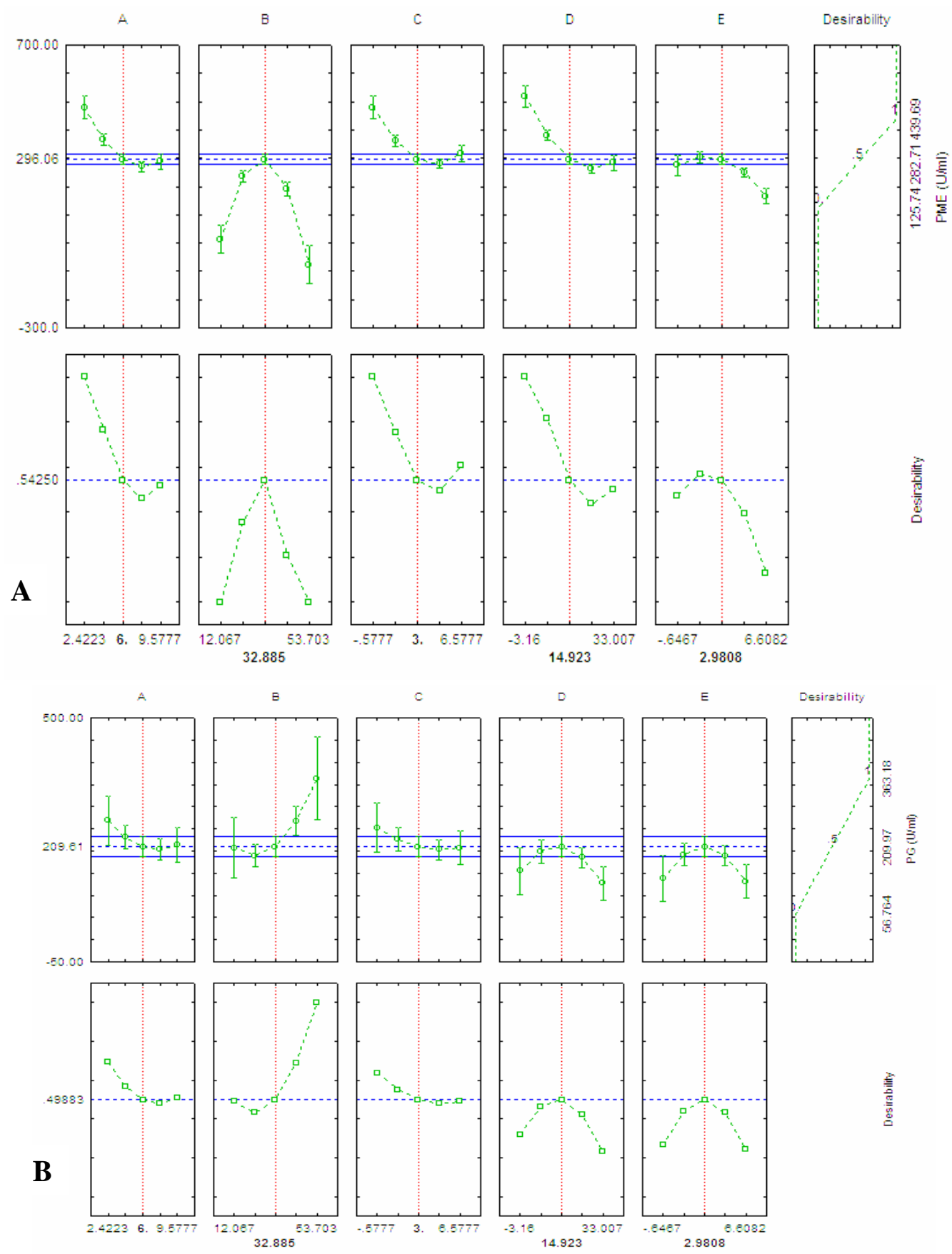

Fig. 4. Desirability chart for PME (A) and PG (B) production by S. commune. 
the growth of microorganisms in solid state fermentation thus reducing the production of pectinolytic enzymes. Shweta et al. (2016) studied the use of response surface methodology (RSM) to optimize ecological factors for pectinase production from Rhizopus sp. Palaniyappan et al. (2009) also studied optimization method using RSM to monitor the effect of different parameters on pectinase production.

From the results of the present study it may also be concluded that mosambi peels which are inexpensive can produce maximum activity of PME and PG. Pure commercial pectin is too expensive to be used as substrate so mosambi peels are best alternative as a source of pectin substrate. So it is suggested that mosambi peels may be a good alternative for PME and PG production from industrial point of view. So the optimum conditions for maximum PME activity were $\mathrm{pH} 6$, temperature $35^{\circ} \mathrm{C}$, time period 3 day, substrate concentration $3 \mathrm{~g}$ and $3 \mathrm{ml}$ inoculum size, which on validation produced PME activity of $394.82 \mathrm{U} / \mathrm{ml}$. Whereas, PG gave maximum activity at $\mathrm{pH} 4$, temperature $45^{\circ} \mathrm{C}$, time period of 5 day, substrate concentration $25 \mathrm{~g}$ and $1 \mathrm{ml}$ inoculum size. And these results was in good confirmation with the predicted values thus proving the accuracy of the model.

The production of PME and PG by mosambi peels is a suitable way of converting agroindustrial wastes into useful products. The results of the present study revealed that Schizophyllum commune can produce PME enzyme using agricultural residue like mosambi peels as a substrate in solid state fermentation. Results of this study showed that nutrients and cultural properties played a crucial role in enzyme production. The optimizations of all the parameters are being considered as pre-requisites to make the process of enzyme production inexpensive at industrial scale. The projected model is effective to be used for fruit juice industry and detergent industry.

\section{Acknowledgments}

The authors would like to acknowledge the Department of Biochemistry and Biotechnology, University of Gujrat (UOG), Pakistan for providing experiment facilities. Special thanks to Dr. Muhammad Irshad (late) for guidance and valuable suggestion for completion of this project form UOG. This research was a part of the NRPU funded project from HEC being run at University of Gujrat by Dr. Muhammad Irshad (late).

\section{References}

Alcantara SR, Francisco AC, Almeida D, Flavio LH and Silva D 2010. Pectinases production by solid state fermentation with cashew apple bagasse: Water activity and influence of nitrogen source. Chem. Engine. Tran. 36: 121-126.

Ali MB, Irshad M, Anwar Z, Zafar M and Imran M 2016. Screening and statistical optimization of physiochemical parameters for the production of xylanases from agroindustrial wastes. Adv. Enzyme Res. 4: 20-33.

Bhargav S, Panda BP, Ali M, Javed S, Bhargav 2008. Solid State Fermentation: An Overview. Chem. Biochem. Eng. Q. 22: 49-70.

Carley KM, Kamneva NY and Reminga J. Response Surface Methodology. CASOS Technical Report. October 2004; CMU-ISRI 04-136.

Demirdoven A and Baysal T 2014. Optimization of Ohmic heating applications for pectin methylesterase inactivation in orange juice. J. Food Sci. Technol. 51: 1817-1826.

Hossam S and Hamdy 2011. Purification and characterization of pectin lyase produced by Rhizopus oryzae grown on orange peels. Annl. Microbiol. 55: 205-211.

Hubert KKD, Parfait KEJ, Constant YJ and Kablan T 2017. Partial purification and Characterization of Two Pectinases (Polygalacturonase and Pectin lyase) from Papaya Pericarp (Carica papaya cv. solo 8) Int. J. Curr. Microbiol. App. Sci. 6: 2729-2739 
Jesus A. Tovar S, Adriana C, Gallegos F, Juan C, Esquivel S, Garcia E, Jesus A, Chavez M and Herrerar RR 2017. Analytical Methods for Pectin Methylesterase Activity Determination: A Review. Food Anal. Methods. 10: 3634-3646.

Kushani R, Ziaee E, Niakosri M and Golmakani T 2014. Optimization of thermal and thermosonication treatment on pectin methyl esterase inactivation of sour orange juice (Citrus Aurantium). J. Food Process. Preserv. 39: 567-573.

Marcos AB, Ricardo ES, Eliane PO and Villar LS 2008. Response surface methodology as a tool for optimization in analytical chemistry. Talanta. 76: 965-977.

Mehmood T, Saman T, Irfan M, Anwar F, Ikram MS, Tabassam Q 2018. Pectinase production from schizophyllum commune through central composite design using citrus waste and its immobilization for industrial exploitation. Waste Biomass Valor. https://doi.org/10.1007/s12649-0180279-9

Murudula S and Anitharaj R 2011. Pectinase production in solid state fermentation by Aspergillus niger using orange peels as substrate. Global. J. Biochem. Biotehnol. 6: 64-71.

Naz S, Irfan M and Farooq MU 2017. Xylanase production from Bacillus subtilis in submerged fermentation using Box- Behenken Design. Pak. J. Biotechnol. 14: 151-156.

Palaniyappan M, Vijayagopal V, Renuka V and Viruthagiri T 2009. Statistical optimization of substrate, carbon and nitrogen source by response surface methodology for pectinase production using Aspergillus fumigatus MTCC 870 in submerged fermentation. Afr. J. Biotechonl. 8: 6355-6363.

Patcharaporn P, Aran HK, Ohsugi, Masahir and Yaowaluk D 2008. Production and Properties of a Fibrinolytic enzyme by Schizophyllum commune BL23. J. Sci. Technol. 30: 447-453.

Poturcu K, Ozmen I, Biyik HH 2017. Characterization of an alkaline thermostable pectin lyase from newly isolated Aspergillus niger WHAK1 and its application on fruit juice clarification. Arab. J. Sci. Eng. 42, 19-29

Renge VC, Khedkar SV and Nikita AR 2012. Enzyme synthesis by fermentation method: A review. Sci. Revs. Chem. Commun. 2: 585-590.

Sandhya R and Kurup G 2013. Screening and isolation of pectinase from fruit and vegetable wastes and the use of orange waste as a substrate for pectinase production. Int. Res. J. Biological. Sci. 2: 34-39.

Shweta H, Nivedita S and Shruti P 2016. Multiple parameter optimization for maximization of pectinase production by Rhizopus sp. C4 under solid state fermentation. Fermentation. 2: 1-9.

Siumara R, Alcantara, Francisco AC, Almeida D and Flavio LH 2010. Pectinases production by solid state fermentation with cashew apple bagasse: water activity and influence of nitrogen source. Chem. Eng. Trans.20: 121-126.

Tapre AR and Jain RK 2014. Pectinases: Enzymes for fruit processing industry. Int. Food Res. J. 21: 447453.

Torres EF, Sepulveda TV and Gonzalez GV 2006. Production of hydrolytic depolymerising pectinases. Food Technol. Biotechnol. 44: 221-227.

Yadav KK, Garg N, Kumar D, Kumar S, Singh A and Muthukumar M 2015. Application of response surface methodology for optimization of polygalacturonase production by Aspergillus niger. J. Environ Biol. 36: 255-9. 